\title{
Intellectual Capital Implementation Strategy Based on the Industrial Revolution 4.0 at the Bandung City Information and Communication Office
}

\author{
Ika Wulandari*, Ramdani Priatna, Fikri Aditya Tri Andikaputra \\ STIA LAN Bandung Polytechnic \\ Bandung, Indonesia \\ *Ika.wldr@gmail.com, priatnaramdani@yahoo.com, fikri@poltek.stialanbandung.ac.id
}

\begin{abstract}
Intellectual capital as an organizational asset is still rarely implemented in Indonesia. Whereas intellectual capital is a very important asset to win the competition and create value for an organization. Intellectual capital can also facilitate intangible resources owned by organizations such as employee competencies, relations with society, and technology. The research method used is qualitative. The results showed that from the perspective of human capital, Bandung City Information and Communication Office can add ASN skills, such as problem solving, creativity, as competencies that are considered unable to be replaced by machines or robots. In the capital structure, it is better to expand Wi-Fi services in the city of Bandung. Besides, it is necessary to add information and communication technology tools as well as system integration to facilitate and simplify the complaint information system. This also relates to aspects of customer capital by creating a good communication flow with other OPD in the Bandung City area.
\end{abstract}

Keywords-intellectual capital, competency, public organization

\section{INTRODUCTION}

The industrial revolution is a major change in terms of humans making goods or services, which are considered capable of changing the structure of life significantly. Starting from the 1.0 industrial revolution which was marked by the presence of the steam engine. Then the industrial revolution 2.0 was marked by a power source. The industrial revolution 3.0 was marked by the presence of computers. The creation of robots, the use of Artificial Intelligent, the Internet of Things, and cloud computing are markers of the 4.0 industrial revolution [1].

Positive impact presence of various technologies are work processes more quickly, efficiently, and accurately. Of course, these various technologies can also be used in public organizations. The President of Indonesia encourages government agencies to use artificial intelligence for various administrative and technical jobs as well as database management in particular and managing the government and the state in general [2].
From the other side, the use of technology also has a negative impact, namely the diminishing of the work of the State Civil Service. The head of Badan Kepegawaian Negara, Bima Haria Wibisana, stated that there is a high probability that $65 \%$ of the work done by the State Civil Service (ASN) will be lost and replaced by machines [3]

Ślusarczyk [4] said that the ability of human resources to adapt to the 4.0 industrial revolution is a very urgent matter. The development of technology typical of the Industria Revolution 4. Have an impact on reducing the need for human labor, which can be replaced by machines, algorithms, or robots. Therefore, one of the most important things for humans to survive is competency development. This was also expressed by an elite organization that holds its annual forum in Switzerland, World Economic Forum (WEF). In an article, WEF explains that reskilling and up skilling must be done so that humans can survive in competing with robots, machines or artificial intelligent.

\section{LITERATURE REVIEW}

The idea of intellectual capital originated in the early 1990s when there was greater attention to the management of intangible assets in various fields. This is also driven by the concept of a "new economy" which is principally driven by developments in information and communication technology. The old reporting system was considered less relevant to the current situation because it was unable to provide important information for decision-making based on knowledge and intangible resources.

In Indonesia, intellectual capital only developed in the early 2000s. This is due to the emergence of Standar Peraturan Akuntansi Keuangan (Revised 2000) on intangible assets related to the field of accounting [5].

\section{A. Intellectual Capital}

Several definitions of intellectual capital, Brooking, define intellectual capital as a term given to a combination of intangible assets in the market, intellectual property, attention 
to human resources, and infrastructure - which can carry out the company's functions [6].

There are 3 intellectual capital, based on Brinker human capital, structural capital and customer capital. Human capital is important for organizations.

Even though machines and computers replace human power a lot, the human role is still there. Human capital is the ability of employees to work and solve problems in the context of serving the community, to innovate, and make reforms. Human capital can be seen from several aspects, namely skills competency, training, and experience. This includes creativity and the nature of innovation. Structural capital is the infrastructure that supports human capital in carrying out its duties. Several things that are included in the type of structural capital are information systems technology, the reputation of the organization. Meanwhile customer capital is the relationship with the community. Examples such as community satisfaction, community profiles, and others.

There has been a lot of literature discussing intellectual capital. However, only a few discussed intellectual capital in public organizations. Among them is the Public Sector Intellectual Capital Model: Efforts towards New Reporting in the Public Sector [7]. Another article discusses the Role of Intellectual Capital in the implementation of New Public Management in Improving Public Sector Managerial Performance [8].

\section{METHODS}

This study uses a qualitative method. The data collected is divided into two (2) types, namely primary data and secondary data. Primary data was obtained through interviews and focus group discussion with related sources, namely speakers from Bandung City Information and Communication Office of Bandung, Bandung City Information and Communication Office of West Java and Badan Kepegawaian Daerah of West Java. Secondary data is obtained through literature and documents related to the research field.

\section{RESULTS AND DISCUSSION}

Bandung City Information and Communication Office (Diskominfo) was one of the regional technical institutions in Bandung. Its function are formulating policies in the scope of communication and information technology; implement scope policy; implementation of evaluation and reporting about communications and informatics; implementation of the office administration in the scope of communication and informatics; and implementation of the functions of the other is given by the Mayor of the City related to the duties and functions.

\section{A. Intellectual Capital}

The concept of intellectual capital used in this study is based on the idea Brinker that consists of human capital, capital structure, and customer capital.

\section{B. Structural Capital}

Structural capital is the supporting infrastructure of human capital as a means and infrastructure to support employee performance including the company's operational system, manufacturing processes, information technology, company operational systems, customer relations, research and development, organizational culture, management philosophy, and all forms of intellectual property owned by the company, to produce the performance of the intellectual enterprise optimized and the performance of the business as a whole. So that even if the employee has knowledge that is high but if not supported by facilities and infrastructure are adequate, then the ability of the employees are not going to generate capital intellectual. An individual has the intellect which is high, but if the company has a system of operation and procedures that bad then the intellectual capital is not able to achieve the performance is optimal and the potential that there is not to be used as a maximum, in accordance with the policy of public SPBE based rule of President Number 952018 concerning SPBE aims to realize a system to manage government that is clean, effective, transparent, and accountable [9].

Some of the problems faced by the Bandung City Information and Communication Office of Bandung based on RPJMD 2018-2023 [10] range of infrastructure and ICT still needs to be improved and the application has not been integrated. The solution can be given, first, there should be equitable access to Wi-Fi. Lots of applications are present as services provided by the Bandung City Government. Based on the website https://ppid.bandung.go.id/ there are 394 applications owned by the city of Bandung. So that the application can be used optimally, Wi-Fi is needed so that people can access it easily. Second, for service effectiveness and efficiency, this agency can also use some of the latest technologies such as artificial intelligent, and the Internet of Things, to support Bandung as a Smart City [11]. Third, build an integrated service information system and database integration. This is also in accordance with the organizational program that manages communication and information technology as stated in the 2019-2023 strategic plan [12].

\section{Human Capital}

The results of the discussion and interviews of speakers from the Bandung City Information and Communication Office explained that there was no competency mapping that was in accordance with the revolution of industry 4.0 which was caused by several obstacles. Based on this, a human capital strategy design was carried out which also refers to the Regulation of the Ministry of Administrative and Bureaucratic Reform No.38 of 2017. The regulation describes 3 types of competencies, namely managerial competence, sociocultural competence, and technical competence [13]

In this study competencies were taken which were taken from several kinds of literature [14,15] are creativity and problem-solving. Creativity means creating. The definition of creativity is creating something that can be useful for solving a problem. Based on the articles of the World Economic Forum 
creativity is important and can be human excellence to compete with artificial intelligence. Creativity is also closely related to innovation which is also important for the management of public organizations. Innovation in public organizations is a very important thing capable contribute to the nation and compete on a global [16]. Gibson [17] states that human creativity is making ideas. Innovation is a way to introduce the idea was to give the price or social value therein.

Complex problem solving is the ability to see problems from various points of view and look for various solution options and choose the best solution. Some of the advantages of this competency are able to solve complex problems; making decisions or steps that have never been done before; have a comparative expertise in thinking compared to individuals who do not have this ability.

The two competencies mentioned above, in addition to complementing existing competencies, are also human abilities that are considered unable to be replaced by artificial intelligence or other technologies that are increasingly developing, especially in the current era of industrial revolution 4.0.In addition, technical competencies that are relevant to structure capital are competencies related to artificial intelligence, the internet of things, big data management, and others related to the industrial revolution 4.0.

\section{Customer Capital}

Defined as organizational asset seen from a customer perspective. There are 2 main services, namely the Information and Documentation Management Officer (PPID) and the People's Online Aspiration and Complaints Service (Lapor). PPID is made to facilitate the public disclosure and updating of website-based information desk services directly and serving via media such as websites PPID. Meanwhile, Lapor is the delivery of the aspirations and complaints people can through multiple channels that can be accessed through www.lapor.go.id.

The results from interview and news search, one of service the Office of Communications and Information Technology of Bandung get an awards competition PAN 2020 Management Complaint Services Public National Year 2020 category of Outstanding Achievement [18]. This award is a component of the assessment of efficiency, trust, reliability, service, convenience, information availability, and interaction. So that, when viewed in terms of customer capital the Bandung City Information and Communication Service, is good enough. However, there are a few things that can be added. This is based on the previous literature which discusses Report! Bandung City [19]. The first is the problem respond complaint. The second is the speed of response. Both of these should also begin with the use of artificial intelligence or the Internet of Things could go faster and more effectively. The third is the awareness of the Bandung City community of service applications. This also relates to structural capital which can be resolved through 1 . Communication flow that can also be facilitated by an integrated information system between the communication and informatics office and other regional apparatus organizations in the city of Bandung so that the flow of communication runs smoother and faster. 2. Supervision of procedures, so that all reports are handled immediately by the related organizations. 3. Besides that, socialization about services can also be done.

\section{CONCLUSION}

Adjustment of competence and infrastructure with the 4.0 industrial revolution is something that is absolutely needed by public organizations, including the Bandung City Information and Communication Office which is the reference for other agencies in the Bandung city government in developing communication and information technology.

The adjustment is made through the concept of intellectual capital which is considered relevant to the current situation. Taking into account competence and technology as assets. Developing, structural capital, human capital, customer capital in accordance with applicable regulations and adjusted to the competence of the industrial revolution 4.0.

\section{REFERENCES}

[1] Mix. M. Communication, Industri 4.0: Ketika Dunia dalam Satu Genggaman. Jakarta: Asoka Aksara, 2019.

[2] Kementrian Kesekretarian Negara Republik Indonesia, "Pemanfaatan A untuk Ringankan Tugas ASN dan Birokrasi," [Online]. Retrieved from: https://setneg.go.id/baca/index/pemanfaatan_ai_untuk_ringankan_tugas_ asn_dan_birokrasi [Accessed on: 2019, December 2]

[3] BKN, "Sebanyak-65-pekerjaan-yang-ada-saat-ini-akan-hilang-pada-10 tahun-mendatang," [Online]. Retrieved from: https://www.bkn.go.id https://www.bkn.go.id/berita/sebanyak-65-pekerjaan-yang-ada-saat-iniakan-hilang-pada-10-tahun-mendatang [Accessed on: 2018, August 23].

[4] N. Dhanpat, Z.P. Buthelezi, M.R. Joe, T.V. Maphela, and N. Shongwe, "Industry 4.0: The role of human resource professionals," SA Journal of Human Resource Management, vol. 18, no. (1), pp. 1-11, 2020.

[5] Dewan Standar Akuntansi Keuangan, Pernyataan Standar Akuntansi. Indonesia: Dewan Standar Akuntansi Keuangan, 2009.

[6] I. Ulum, Intellectual Capital: Konsep dan Kajian Empiris. Yogyakarta: Graha Ilmu, 2006

[7] P. Astuti dan I.K. Kusumawijaya, "Model Intellectual Capital Sektor Publik: Upaya Menuju Pelaporan Baru Sektor Publik," Seminar Nasional Fakultas Ekonomi UNS. Surakarta: Fakultas Ekonomi UNS, 2013.

[8] L. Indrawati, "Peran Intellectual Capital Terhadap Implementasi New Public Management Dalam Peningkatan Kinerja Manajerial Sektor Publik," Ekspansi: Jurnal Ekonomi, Keuangan, Perbankan dan Akuntansi, vol. 8, no. (1), pp. 117-130, 2016.

[9] Peraturan Presiden Nomor 95 Tahun 2018 tentang SPBE.

[10] RPJMD Kota Bandung 2018-2023.

[11] Indah, “394 Aplikasi Untuk Pelayanan Publik Kota Bandung,” [Online]. Retrieved from: https://ppid.bandung.go.id/394-aplikasi-untukpelayanan-publik-kota-bandung/ [Accessed on: 2017, September 28].

[12] Rencana Strategis Dinas Komunikasi dan Informatika Kota Bandung 2019-2023.

[13] Peraturan Kementrian Pendayagunaan Apartur Negara dan Reformas Birokrasi No. 38 Tahun 2017 tentang Standar Kompetensi Jabatan ASN. Republik Indonesia . 
[14] K. Grzybowska and A. Łupicka, "Key competencies for Industry 4.0," Economics \& Management Innovations, vol. 1, no. (1), pp. 250-253, 2017.

[15] M.H. Syarbini, Top Ten Skills For Millennials: 10 keterampilan penting di era industri 4.0. Surakarta: Metagraf, 2020.

[16] T.W. Utomo, Inovasi Harga Mati. Depok: Rajawali Pers, 2018.

[17] R. Gibson, The 4 Lenses of Innovation A Power Tool for Creative Thinking. New Jersey: John Wiley and Sons, 2015.
[18] https://www.jabarprov.go.id/index.php/news/40446/2020/12/03/Bandun g-Raih-Penghargaan-dari-Komisi-Informasi

[19] R. Pramudita, N. Safitri, and S. Solikin, "Sistem Informasi Pelayanan Pengaduan Masyarakat di Dinas Komunikasi dan Informasi Kota Bandung," Information System For Educators And Professionals: Journal of Information System, vol. 2, no. (1), pp. 11-20, 2017. 